\title{
長期波浪推算結果に基づく日本沿岸の波浪特性 WAVE CHARACTERISTICS IN JAPANESE COAST BASED ON LONG-TERM WAVE ESTIMEIONS BY WAVE MODEL
}

\author{
川口浩二1 \\ Koji KAWAGUCHI \\ 正会員 博 (工）（独法）港湾空港技術研究所 海洋情報研究領域 海象情報研究チーム リーダー \\ ( ₹239-0823 神奈川県横須賀市長瀬3-1-1)
}

\begin{abstract}
It is important to understand the wave characteristics in a Japanese coast in relation to global warming and so on. Ocean waves in Japanese coast have been observed routinely since the 1970's by NOWPHAS (Nationwide Ocean Wave information network for Ports and Harbors), and those wave data for a long term are useful to examine wave characteristics in Japanese coast. However, those wave data are not necessarily observed under the same condition during the observation.

This study examined wave characteristics in the Japanese coast based on long-term wave estimations by $3^{\text {rd }}$ generation wave model WAM. As a result, remarkable secular variation of yearly average of waves was not able to be confirmed.
\end{abstract}

Key Words : Wave characteristics, wave climate, wave estimation, $3^{\text {rd }}$ generation wave model, WAM

\section{1.はじめに}

我が国では，1970年代から運輸省（当時）による 波浪の定常観測が始まり，現在，日本沿岸に約70の 波浪観測地点を有する全国港湾海洋波浪情報網 ${ }^{112)}$

（ナウファス）によって，波浪観測データの蓄積が 日々行われている。ナウファスの波浪観測データは, 国土交通省などが実施する港湾事業の計画・調査・ 設計・施工などで必要となる波浪条件を設定するた めに用いられる他, 気象庁による波浪予報にも活用 されている.さらに，ナウファスでは，観測地点に よっては，40年程度の長期間の波浪観測データが蓄 積されていることから, 地球温暖化に関連して, 日 本沿岸での長期的な波浪の出現特性を検討する際の 貴重な観測データとしても期待されている。しかし， ナウファスの波浪観測データは実測された波浪では あるが，観測機器や観測位置などの観測条件の変更 や観測データの測得や解析方法など，観測期間を通 して同一な条件下での波浪観測データとは限らない. さらには，海底設置式の波浪計は設置水深や設置場 所等の制約から局所的な地形の影響を受けている場 合もあり，観測された波浪が必ずしも海域を代表す る波浪観測データでない可能性もある。

近年，波浪モデルの高度化や気象に関する長期間 の再解析データ（以下では気象GPVと記す）が提供 されるなど，過去に遡って手軽に長期の波浪推算が 実施できる環境となってきた。そのため，長期間の 波浪推算結果を基にすれば，既に述べた波浪観測 データが有する問題点を極力排除した日本沿岸での
長期的な波浪特性の検討が可能であると考えられる. 本研究では，気象GPVおよび第3世代波浪推算モデ ル WAM ${ }^{3)}$ に基づく長期間の波浪推算結果を基に日本 沿岸における長期的な波浪の出現特性を検討した.

\section{2. 波浪観測と波浪推算による波浪データ}

図-1は，ナウファスの波浪観測地点図を示してい る. 2009年12月現在, 観測地点は72地点であるが, このうち1970年代前半から現在も継続的に波浪観測 を実施しているのは13地点である。そのため，これ らの地点では, 波浪観測データの蓄積が 40 年近くに 達しており，本研究の目的である波浪の長期的な特 性を検討する上で有益なデータと考えられるが，そ のデータの取り扱いには注意を要する.

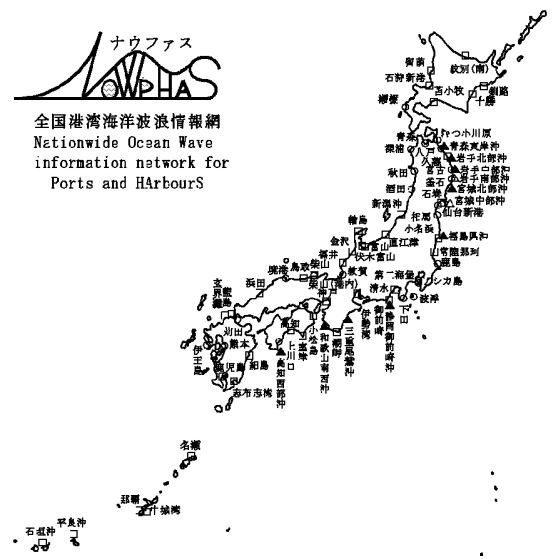

図-1 ナウファス波浪観測地点（2009. 12現在） 
表-1は，1970年代から観測を実施している観測地 点Aにおける観測条件の履歴を示したものである. 表から観測開始から現在までの間に2度の観測機器 の変更があった。そして，そのうち1回目の機器変 更では，設置水深が深くなっていることから，設置 位置も変更されていることがわかる.

表-1 観測地点Aにおける観測条件の履歴

\begin{tabular}{|c|c|c|}
\hline 観測機器 & 設置水深 & 観測期間 \\
\hline PW & 12.8 & $1970.8 \sim 1986.11$ \\
\hline USW & 54.7 & $1987.1 \sim 1997.8$ \\
\hline DWDM & 54.7 & $1998.8 \sim$ 現在 \\
\hline
\end{tabular}

※ PW: 水圧式波高計, USW : 超音波式波高計, DWDM:海象計

図-2は，同じ観測地点Aにおける波浪観測データ の年平均有義波（有義波高と有義波周期）とデータ 測得率の経年変化を, 各観測機器の期間と共に示し たものである。ここで，1998年は，機器更新に伴う 久測が長期間に渡ったため，欠測年という扱いに なっている。困から，1987年すなわち1回目の機器 変更の前後で，年平均有義波の值が明らかに異なっ ていることがわかる。これは，表-1に示したように 観測機器の更新に伴って, 観測位置の変更に起因し ていると考えられる.

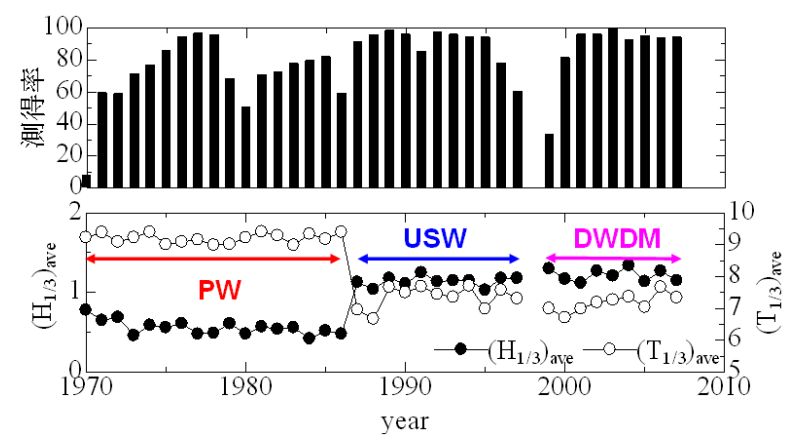

図-2 観測地点Aにおける年平均有義波と データ測得率の経年変化と波浪観測機器の履歴

図-3は，日本海側に面した観測地点Bにおける波 浪観測データの年平均有義波と観測データの測得率 の経年変化を示したものである. 図から，1980～83 年，1995および1996年の年平均有義波高が他の年と 比べて明らかに大きくなっていることがわかる。そ して，これらの年のデータの測得率を見ると最大で も30\%以下と極端に低く，1996年にいたっては10\%を 切っている. そのため, これらの年の測得状況を確 認したところ, 概ね冬季のみしか測得できていない ことが分かった。日本海側に面した観測地点Bでは， 夏季は波高が小さく，冬季は波高が大きいという季 節的な波浪特性があると考えられるが，これらの年 については，測得できた冬季のデータのみで年平均 を算出したため, 見かけ上, 年平均波高が大きく なったと推察される。

図-2の観測地点Aは極端な例であるが，波浪観測
データを用いて, 波浪の経年変化等を検討する際に は，観測条件の履歴や観測データの測得率（測得状 況）などにも注意する必要がある。

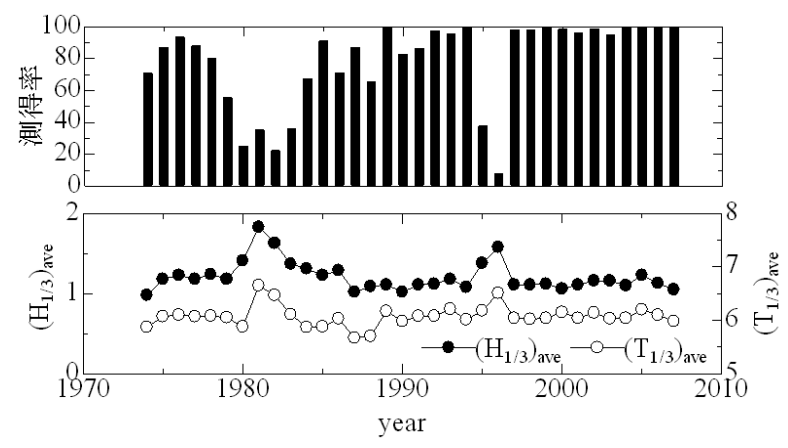

図-3 観測地点Bにおける年平均有義波と データ測得率の経年変化

本研究では，このような波浪観測データに内在す る問題点を可能な限り排除するために，第3世代波 浪推算モデルWAMによる長期間の波浪推算結果を基 に，日本沿岸の長期間の波浪特性を検討することと した.

長期間の波浪推算を実施するには，長期間の気象 GPV（海上風データ）が必要となる。長期間の気象 GPV としては，気象庁と (財) 電力中央研究所による JRA-25 ${ }^{4) 5}$ ）（データ提供期間は1979年〜2004年の 26 年間），米国NCEP／NCARのReanalysis1 6)（データ 提供期間は1948年〜現在）などがあるが, 本研究で はECMWF（ヨーロッパ中期予報センター； European Centre for Medium-Range Weather Forecasts) か ら提供されている気象GPV（データセット名; ERA407)）を用いることとした。 なお，ERA-40の海上風 の推算精度検証については洋上における風観測デー タがそしいことから困難であるが，小林・佐々木・ 吉野・安田 ${ }^{8)}$ によれば，天気図との比較および有義 波高の再現性から間接的ではあるが十分な精度を有

しているとしている.

近年, 気象庁などから高解像度の気象GPVが入手 可能となっているが，一般的に気象GPVによる波浪 推算は気象 $\mathrm{GPV}$ の時間・空間的な解像度の制約から, 風場（風速）が過小評価傾向であるといえる。本研 究で用いたERA-40によるWAMの波浪推算結果につい

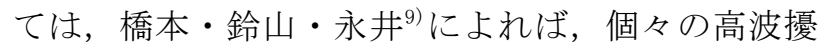
乱の波高ピーク時付近では観測波高よりも小さく推 算される傾向があるが，月別や経年変化などの統計 的な変化傾向を把握するためには有用であると報告 している。図-4は，ナウファスの波浪観測地点（中 城湾 ; 後述の図-6参照）におけるナウファスの観測 值（Obs.）とWAMの波浪推算值（Cal. ）の年平均有 義波高の経年変化を観測值の測得率と共に示したも のである。この図から, 測得率の低い年では差違が みられるが，それ以外では概ね一致していることが 分かる.そのため本研究では個々の值というよりは， 值の経年的な変化傾向に着目して検討を行った。 


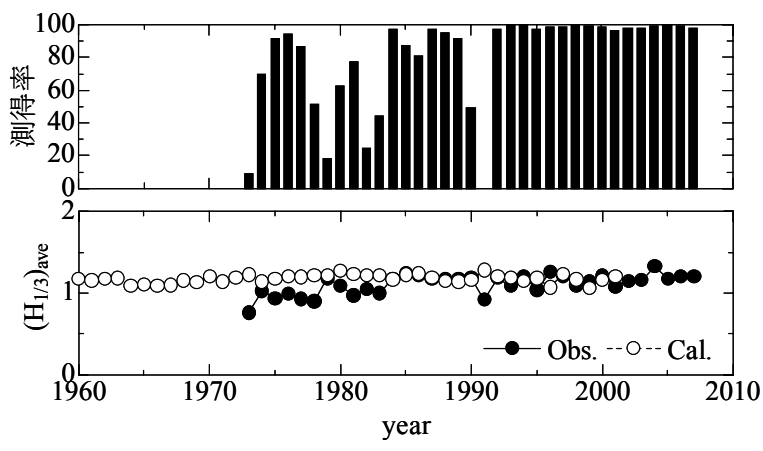

図-4 観測值と推算值による年平均有義波高の比較例

表-2はERA-40の仕様を，表-3および図-5には波浪 推算の計算領域・計算条件等を示している。WAMに よる波浪推算はERA-40の提供期間で実施したが，取 りまとめに際しては，1960～2000年の41年間を用い ることとした。

表-2 気象GPV(ERA-40)の仕様

\begin{tabular}{c|c}
\hline データ提供範囲 & 全球 \\
\hline 空間解像度 & $1.125^{\circ}$ \\
\hline データ提供期間 & $1957 \sim 2002$ 年 \\
\hline 時間解像度 & 6 時間 \\
\hline
\end{tabular}

表-3 波浪推算の計算条件等

(a)計算領域

\begin{tabular}{c|c}
\hline \multirow{2}{*}{ 計算範囲 } & 北緯 $15^{\circ} \sim 63^{\circ}$ \\
\cline { 2 - 2 } & 東経 $115^{\circ} \sim 170^{\circ}$ \\
\hline 格子間隔 & $0.5^{\circ}$ \\
\hline 格子数 & $111 \times 97$ \\
\hline
\end{tabular}

(b)計算条件

\begin{tabular}{c|c}
\hline 計算時間間隔 & 1,200 秒 \\
\hline 海上風の入力時間間隔 & 6 時間 \\
\hline \multirow{2}{*}{ 波浪スペクトル分解能 } & 25 (周波数分割数) \\
\cline { 2 - 2 } & 16 (方向分割数 $)$ \\
\hline 出力時間間隔 & $\begin{array}{c}\text { 1時間 } \\
\text { そ深海条件 } \\
\text { そ水深情報無し) }\end{array}$ \\
\hline
\end{tabular}

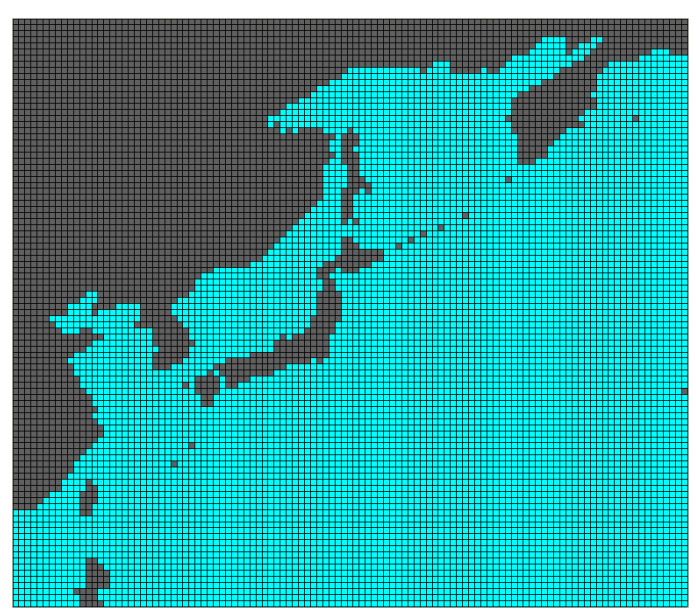

図-5 波浪推算の計算領域
検討対象地点は, 日本沿岸を網羅的に検討するた め，ナウファス波浪観測地点を参考に，図-6に示す 計8地点（紋別，むつ小川原，鹿島，潮岬，中城湾， 留萌, 輪島, 浜田) を選定し, 各観測点位置に最も 近い計算格子点における波浪推算結果を用いた。

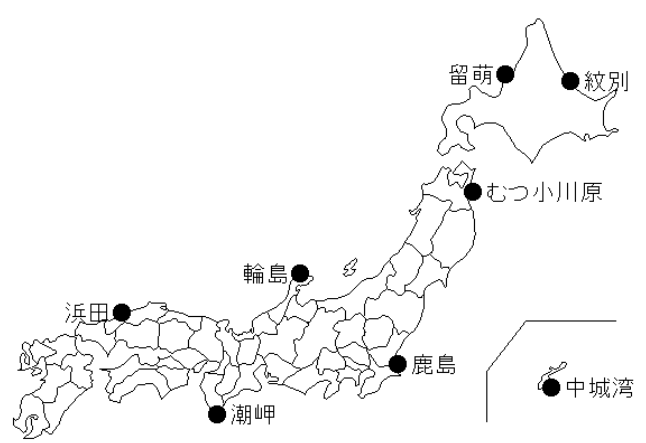

図-6 検討対象地点（全8地点）

\section{3. 検討結果}

以下では，波浪統計量毎に検討結果を示す。

（1）年平均有義波

図-7は，対象全8地点について，年平均有義波の 経年変化を, オホーツク海と太平洋側の計5地点, 日本海側の計3地点に分けて示したものである。こ れらの図から, 年平均有義波高については, 各地点 ともに年毎に多少のばらつきはあるが，顕著な経年 的な変化傾向は確認されなかった.

一方，年平均有義波周期については，日本海側の 3地点については経年的な変化傾向は見られないが, 太平洋側については，1960年代では年毎の值の変化 は小さいが，次第に年毎の值の差違が大きくなって おり，鹿島のように若干の増加傾向にあるようにも みえるが，顕著な経年変化とまでは言えない。
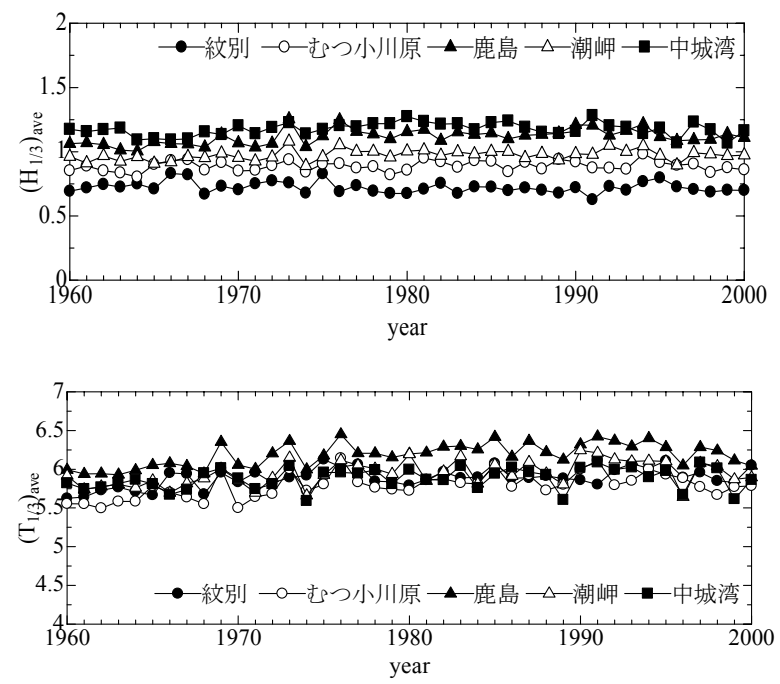

(a) オホーツク海・太平洋側

図-7 年平均有義波の経年変化

（上から, 年平均有義波高 - 年平均有義波周期） 

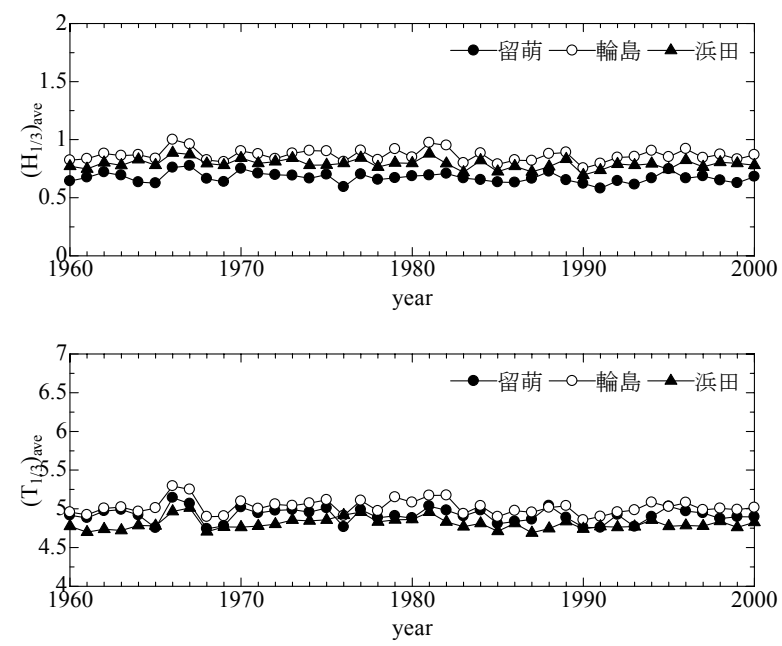

（b）日本海側

図-7 年平均有義波の経年変化（続き）

（上から, 年平均有義波高・年平均有義波周期）

\section{（2）季節別平均有義波}

ここでは，季節別平均有義波について記すが，季 節の定義は，冬季（前年12月～2月），春季（3月〜 5月），夏季（6月～8月）および秋季（9月～11月） とした。なお，1960年の冬季についても前年1659年 12月～1960年2月の推算結果を用いている.

図-8は，輪島および潮岬について，季節別平均有 義波の経年変化を示したものである。これらの図か ら，輪島では，冬季で波高と周期が大きく，逆に夏 季は小さいという，一般的に日本海側でみられる季 節的な出現特性があることがわかる。また，年によ る值の変動についても, 冬季に大きく, 夏季に小さ いことがわかる。

一方, 太平洋側の潮岬では，波高については年に よる值の変動はあるものの, 輪島でみられたような 顕著な季節的な特性はないことがわかる。また, 周 期については，年による值の変動が大きく，秋季の 值がやや大きいことがわかる. なお，ここでは図示 していないが，日本海側の留萌・浜田についても輪 島と同様の季節的な特性を有していた。また，太平 洋側については，むつ小川原で冬季の波高がやや大 きいという日本海側に見られる季節的な特性がみら れたが，他の太平洋側の地点では潮岬と同様，日本 海側のような明確な季節的な特性や経年的な変化傾 向は確認できなかった。

\section{(3) 季節別静稳率}

ここでは，有義波高 $1 \mathrm{~m}$ 以下を静穏と定義し，その 割合・静穏率（\%）の経年変化を季節別に調べた。

図-9は，その結果の一例（浜田と鹿島）である. 図-8の輪島と同様，日本海側の浜田でも冬季の波高 は大きく，夏季は小さいという季節的な特性がある が，それが静穏率にも表れている。すなわち，波高 の小さい夏季では静穏度が概ね $290 \%$ 以上と高く, 年 による值の変動も小さい。一方，冬季の静穏率は概 ね $40 \%$ 程度と低く, その範囲も30～60\%程度と年によ る変動が大きいことがわかる。また，春季および秋
季の静穏率はその中間であり, 春季は $80 \%$ 程度, 秋 季はやや下がって70\%程度という結果であった。こ のような傾向は，地点によって，程度の差はあるが， 他の日本海側地点でも同様の結果であった。

一方, 太平洋側の鹿島では, 夏季の静稳率が他の 季節よりもやや高いが，概ね $50 \%$ 程度と同じような 值を取っていることがわかる。しかしながら, 年に よる值の変動は大きく, 日本海側のそれと比べても 大きいことがわかる。このような傾向は，冬季の日 本海側のような傾向がみられたむつ小川原を除き, 他の太平洋側地点にでも概ね同様の傾向であった.
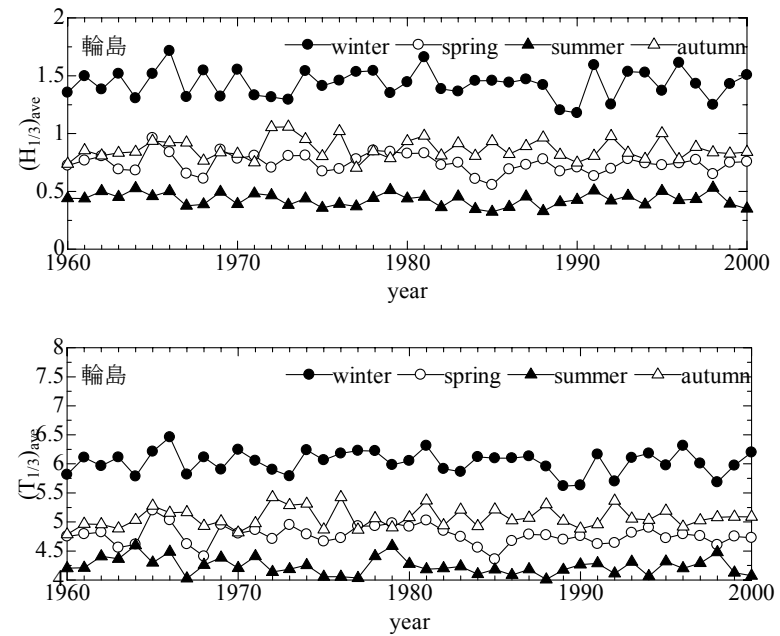

(a) 輪島（日本海側）
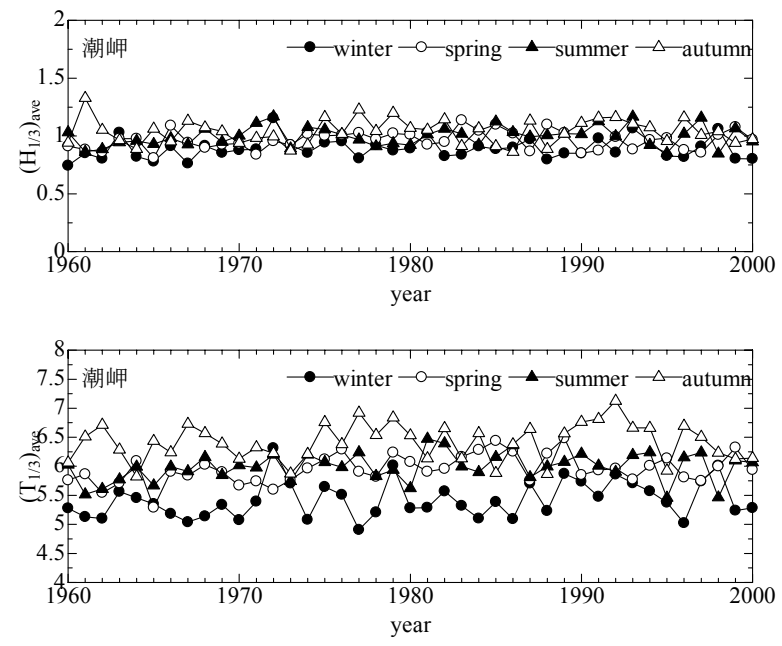

(b) 潮岬（太平洋側）

図-8 季節別平均有義波

（両地点とも，上から有義波高・有義波周期）

\section{（4）波高年間上位の波浪}

ここでは，各年における波高年間上位3位までの 高波に着目して検討した。高波擾乱とは有義波高が ある閾值を超えた後, 再び閾值を下回るまでを高波 擾乱期間と設定し，その間の最大有義波高をその擾 乱の高波とした。そして, 各年で高波擾乱の最大有 義波高の年間上位3位までを抽出し, 本検討の対象 とした. 


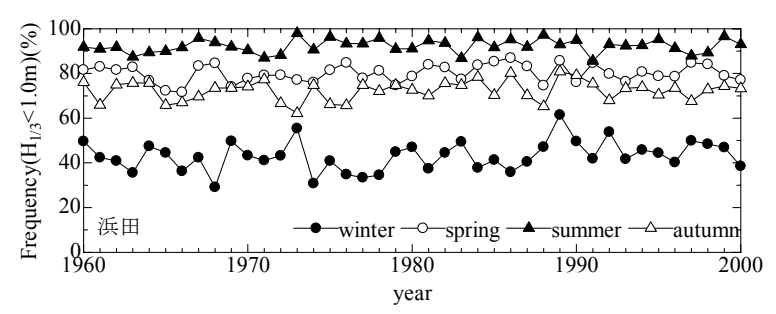

(a) 浜田（日本海側）

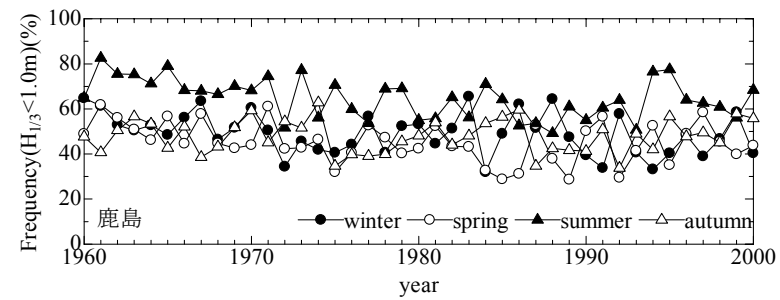

(b) 鹿島（太平洋側）

図-9 季節別静穏率

図-10は，各年の高波年間上位3位までの各擾乱の 最大有義波とそれらの平均值の経年変化を示したも のである。オホーツク海側の紋別では，年間1位の 波高が2位・3位と比べて突出している年が期間を通 して見られるが，1974年をピークに，突出した年間 1位の波高が減少傾向になっている.

一方，日本海側の浜田では，年間1位の波高が， 年間2位および3位と比べて突出している年が数年あ るが，期間全体を通して見れば高波上位3位までの 波高には大差がないことがわかる。また，周期につ いても同様の事が言える.

さらに，太平洋側の中城湾では，1960年代は年間 上位3位までの波高の差はさほど無いが，1970年代 から年間1位が2および3位と比べて大きい年が見ら れるようになり，1980年以降では，その頻度がより 顕著になってきているようにみえる。また，周期に ついても，波高ほどではないが，同様の傾向がみら れる.

このように，波高年間上位に着目した場合は，若 干の経年的な変化傾向が確認された。しかしながら, 冒頭で書いたように，ERA-40を直接用いた個別の擾 乱の波浪推算の精度に関しては，引き続き検討が必 要である。

\section{4.おわりに}

第3世代波浪推算モデルWAMによる長期間の波浪推 算結果を基に，日本沿岸の全8地点を対象に波浪特 性を検討した結果，以下のことがわかった。

(1)年平均有義波については，顕著な経年変化の傾向 は確認できなかった。

(2)季節別平均有義波については，海域による季節的 な特性が確認され，日本海における冬季の波高な どでは年変動が大きいことがわかった。しかし，
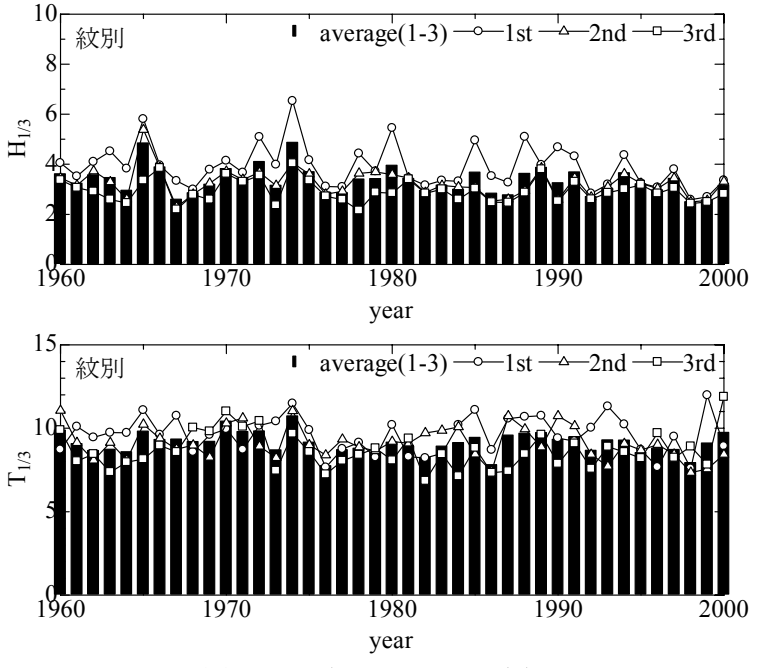

（a）紋別（オホーツク海）
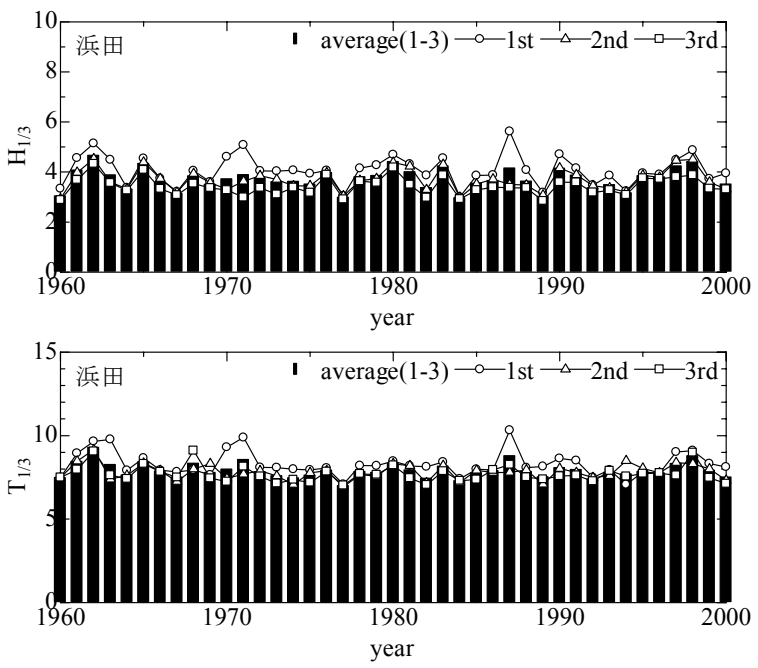

(b) 浜田（日本海）
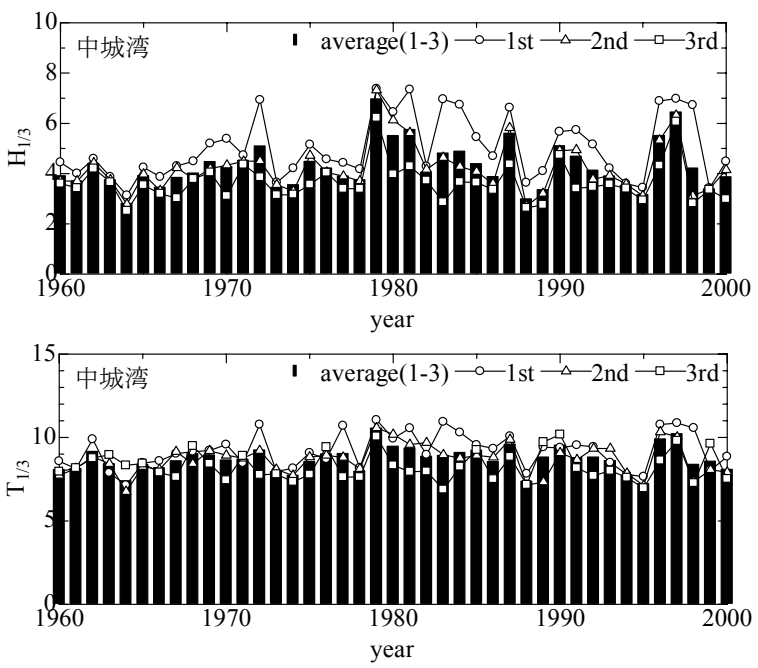

(c) 中城湾 (太平洋)

図-10 年高波上位 1 ～位における最大有義波とそれら の平均值の経年変化

（各地点とも，上から有義波高，有義波周期） 
年平均有義波と同様に, 顕著な経年変化の傾向は 確認できなかった。

(3)季節別静穏率については, 季節別平均有義波と同 様に, 海域による季節的な特性が確認され, 年変 動が大きいことがわかった。

(4)波高年間上位に着目した検討では，一部の地点に おいて，高波1位の波浪に関して，若干の経年的 な変化傾向が確認された。

謝辞：本研究を実施にあたつて，ERA-40を提供して いただいたECMWFに謝意を表するとともに，本研究 の一部は科研費（90371476）の助成を受けたもので ある。

\section{参考文献}

1) リアルタイムナウファス Web site : http://www.mlit.go.jp/kowan/nowphas/

2) 河合弘泰, 佐藤 真, 川口浩二, 関 克己 : 全国港湾海 洋波浪情報網(NOWPHAS2009), 港湾空港技術研究所 資料, No.1226, 120p, 2011. 他.
3) The WAMDI Group : The WAM model-A third generation ocean wave prediction model, J. Phys. Oceanography. , 18, pp.1775-1810, 1998.

4) 気象庁 JRA-25 web site: http://jra. kishou. go. jp/

5) Onogi, K., J. Tsutsui, H. Koide, M. Sakamoto, S. Kobayashi, H. Hatsushika, T. Matsumoto, N. Yamazaki, H. Kamahori, K. Takahashi, S. Kadokura, K. Wada, K. Kato, R. Oyama, T. Ose, N. Mannoji and R. Taira : The JRA-25 Reanalysis, J. Meteor. Soc. Japan, 85, pp.369-432, 2007.

6) NCEP/NCAR Reanalysis1 web site : http://www.esrl.noaa.gov/psd/data/gridded/ data.ncep.reanalysis.html

7) ECMWF ERA-40 web site: http://www.ecmwf.int/products/data/archive/ descriptions/e4/full.html

8) 小林智尚, 佐々木博一, 吉野 純, 安田孝志: ERA40 に もとづく日本列島周辺長期波浪データベースの構築, 海岸工学論文集, 第 54 巻, pp. 141-145, 2007.

9) 橋本典明, 鈴山勝之, 永井紀彦: ECMWF 風 (Operational data, ERA15, ERA40)による長期波浪推 算精度の検討, 海岸工学論文集, 第 51 巻, pp. 201205, 2004. 